\title{
DUTY AS A DEFENCE BETWEEN CIVIL DISOBEDIENCE AND CRIMINAL LAW
}

\section{L'ADEMPIMENTO DEL DOVERE TRA DISOBBEDIENZA CIVILE E RESPONSABILITÀ PENALE}

\author{
Laura Ciccozzi \\ LL.M. from Queen Mary University of London
}

\begin{abstract}
English: The history of civil disobedience begins in the United States in the 17th century and has evolved during the centuries. The most modern type of civil disobedience, whistleblowing, is emblematic of how the concept has changed over the last decades. The question of which circumstances justify disobedience to the law is one of the most debated in the history of legal thought. The article analyses the relationship between morality and criminal law or, in other words, between the right (and duty) to disobey certain laws and its consequences.
\end{abstract}

Keywords: Civil disobedience; whistleblowing; criminal law; legal duty; moral duty

Abstract Italiano: La storia della disobbedienza civile inizia negli Stati Uniti nel XVII secolo. II whistleblowing, come atto di disobbedienza civile tipico dell'età contemporanea, è emblematico dell'evoluzione del concetto attraverso i secoli. La questione di quali circostanze giustifichino la disobbedienza alla legge è fra le più dibattute nella storia del pensiero giuridico. L'articolo analizza, in particolare, il rapporto tra morale e diritto penale $\mathrm{o}$, in altri termini, tra il diritto (e dovere) di disobbedire alla legge in determinate circostanze e le conseguenze di tale disobbedienza.

Parole chiave: Disobbedienza civile; whistleblowing; responsabilità penale; dovere giuridico; dovere morale

Table of contents: 1 . The history and features of civil disobedience. -2 . The moral and legal aspects of civil disobedience. -3 . The legal defences for civil disobedience. -4 . A modern kind of civil disobedience: whistleblowing. The Wikileaks case. -5 . Morality and criminal law: why civil disobedience is not a crime. -6 . Conclusion.

\section{The history and features of civil disobedience}

Civil disobedience can be broadly defined as the citizens' right to break the law under certain conditions. Civil disobedience has played a significant role in shaping the history of many countries, especially the United States. American histo-

* Italian Review of Legal History, 7 (2021), n. 15, pagg. 547-562

* https://riviste.unimi.it/index.php/irlh/index

- ISSN 2464-8914 - DOI 10.54103/2464-8914/16897. Articolo pubblicato sotto Licenza CC-BY. 
rians argue that dissidents founded the United States. Indeed, from the abolitionists to the suffragettes, from the 1960s anti-war and civil rights movements to Black Life Matters, «dissent has been at the very heart of American civil life ${ }^{1}$ and is still relevant today. The origins of American civil disobedience can be found in the Quaker movement. Quakerism promotes an interpretation of Christian believes based on individual conscience. Quakers believe in "an intimate correspondence between affairs of conscience and those of collective political will, and between the private sphere of religious commitment and the public sphere of social action ${ }^{2}$. Early Quakers rejected slavery and, as early as 1688 , organized the first petition in North America against human trafficking. They were ready to run physical risks and endure imprisonment for their beliefs and refused to take up arms and to participate in the financing of armed conflicts: "a series of characteristics that became broadly common across civil disobedience actions» ${ }^{3}$. Piracy - as practiced in the North American colonies during the British dominion - has also been defined as "a nascent form of rebellion" ${ }^{4}$, whereas the "attempts by the Crown to restrain the pirate trade were widely regarded as a ploy to reinstate the 'chains of bondage' on the people ${ }^{5}$. This peculiar alliance among pirates, smugglers, merchants and local governors led to the creation of a new colonial model as opposite to the restraints imposed by the Crown.

Although the most important philosophers - from Augustine of Hippo and Thomas Aquinas to Thomas Hobbes - had already recognized the legitimacy of actions of civil disobedience, the term itself was created in the 19th century by the American philosopher Henry David Thoreau (the essay Resistance to Civil Government - also known as On the Duty of Civil Disobedience - was published in 1849). Thoreau's conception of civil disobedience is based on two principles: "the authority of government must have the sanction and consent of the governed [and] the only obligation that men have the right to assume is to do at any time what they think right ${ }^{6}$.

Civil disobedience has evolved during the centuries and today its features are profoundly different, even in comparison to a few decades ago. Scholars highlight how

global civil society is now comprised of 'trans-national citizens', whose strongest attachment and allegiance is no longer necessarily that to their home countries, but it may well be to a specific transnational community, cultural group, or it may even consist in a somewhat cosmopolitan commitment to groups whose principles they share. These may be groups committed to the environment, to the reduction

\footnotetext{
${ }^{1}$ Westra, 2014, p. 29.

${ }^{2}$ Hayes, Ollitrault, 2018, pp. 143-145.

${ }^{3}$ Ibidem, p. 145.

${ }^{4}$ Burgess, 2014, p. 8.

${ }^{5}$ Ibidem, p. 10.

${ }^{6}$ Thoreau, 2008, pp. 440 and 473.
} 
of global warming, or to social and legal justice. [...] It is from the standpoint of any of those principled, global platforms, that the newly emerging transnational citizen judges and often convicts his home country?

Social protest movements transformed the relationship between the citizens and the State, giving the former the opportunity to express their conscientious objection against a law or policy that they perceive as immoral or illegal. Indeed, civil disobedience is a form of conscientious objection that, additionally, involves a public action. If conscientious objection is a private act, whose "sole purpose is to allow the conscientious objector to follow his conscience by disobeying legal rules in conflict with it ${ }^{8}$, civil disobedience can be defined as "a public, non-violent and conscientious act contrary to law usually done with the intent to bring about a change in the policies or laws of the government»?.

In spite of the broad definition, all the acts of civil disobedience have some common features. First, they are political acts, motivated by «a belief that a law or policy is wrong or otherwise mistaken ${ }^{10}$.

Secondly, within a democratic regime civil disobedience is not a normal political action, but «a last resort when standard democratic processes have failed $»^{11}$. In a free and democratic society, breaking the law is not justified until all the legal means have first been exhausted. Yet, it is undeniable that throughout history the behaviour of the champions of civil disobedience was regarded as illegal by their contemporary authorities. People like Jesus Christ, Gandhi and Martin Luther King acted in violation of the law in order to express dissent, thus provoking the response of the criminal justice system. Indeed, crime may be a necessary antecedent to significant social change. The abolition of slavery, the introduction of labour laws, women's suffrage or civil rights legislation are just «some of the widely acknowledged historical contributions of illegal actions to the struggle and ultimate attainment of social justice along various political axes $»^{12}$. In 1903, Émile Durkheim - one of the fathers of criminology - referred to «people who openly challenge legal boundaries as the great moral innovators of society ${ }^{13}$. Nonetheless, the acts of civil disobedience are traditionally non-violent offenses.

Finally, the acceptance of punishment is considered an essential feature of civil disobedience, as opposed to common crime. The civil disobedient accepts arrest and punishment without resistance or, in other words, agrees to "remain and drink the prescribed hemlock» ${ }^{14}$ like Socrates did. This is the peculiarity of

\footnotetext{
${ }^{7}$ Westra, 2014, p. 25.

${ }^{8}$ Nehushtan, 2017, p. 435.

${ }^{9}$ Rawls, 1999, p. 54.

${ }^{10}$ Jones, 2004, p. 321.

${ }^{11}$ Rawls, 1999, p. 57.

12 Lovell, 2009, p. 9.

${ }^{13}$ Ibidem, p. 16.

${ }^{14}$ Pineda, 2015, pp. 2-4.
} 
civil disobedience as a political act: the perpetrator breaks and respects the law at the same time because he is eager to face the consequences of his unlawful conduct ${ }^{15}$. In the words of the 'father' of civil disobedience, Thoreau: «under a government which imprisons any unjustly, the true place for a just man is also a prison [...] to be put out and locked out of the State by her own act, as they have already put themselves out by their principles» ${ }^{16}$. Moreover, imprisonment may be a way to strengthen the fight against the authority. The American civil right movement considered mass arrests both as an opportunity of «extending protest into new arenas ${ }^{17}$ and as a way to overcome the system. And this is still valid today: criminal trials are seen as

arenas for political interaction, movement building, and tactical decision-making; they offer regulated, highly codified spaces of engagement in which activists can attempt to secure favourable outcomes, challenge the basis of the laws they have broken, and put the policy or law against which they are protesting 'on trial ${ }^{18}$.

\section{The moral and legal aspects of civil disobedience}

Collective actions of civil disobedience are part of the political life of democratic societies. Therefore,

for many activists, the decision to commit acts of civil disobedience comes not (or not just) from conscience, but from their understanding of their duties as citizens (and in some cases, as professionals). In such cases, disobedience is felt as less a choice than an obligation: to act otherwise is an impossibility ${ }^{19}$.

Indeed, there is a strong connection between the engagement in civil disobedience and the citizen's duty to obey the laws. The citizen who engages in civil disobedience chooses to disobey because he feels that it would be morally wrong to comply with an unjust law.

This aspect of civil disobedience is at the core of the Nuremberg Principles ${ }^{20}$ : if in the Nazi ideology individual conscience must always give way to public interest, the gist of the Principles is that «when individual morality is at odds with

\footnotetext{
${ }^{15}$ Legal protest, on the one hand, and unlawful dissent, on the other hand, define the boundaries of civil disobedience. The first one includes activities that are legal in principle, although they can become illegal under certain circumstances, like authorized demonstrations and boycotting. The second one encompasses a range of unlawful conducts: uncivil disobedience, militant protest, organized forcible resistance and revolutionary action (Rawls, 1999, p. 55).

${ }^{16}$ Thoreau, 2008, p. 454.

${ }_{17}^{17}$ Pineda, 2015, p. 3.

${ }^{18}$ Hayes, 2018, p. 199.

19 Ibidem, p. 185.

${ }^{20}$ The 'Principles of International Law Recognized in the Charter of the Nuremberg Tribunal' codified the legacy of the Nuremberg and Tokyo War Crimes Trials.
} 
State authority, it is the conscience of the individual that must reign supreme ${ }^{21}$. Military law acknowledges conscientious objection as the soldier's right to disobey those orders that he believes to be unjust. The concept was firstly developed by the 17th century Dutch jurist Hugo Grotius. According to Grotius, superior orders are generally presumed to be legal. However, the soldiers, by the very fact that they have a conscience, have also

a fair degree of individual responsibility: they are obliged to inquire into the justice of the cause of war. [...] Conscience, whether it is in accordance with objective justice or not, is always (subjectively) binding. Therefore, it is a sin to act contrary to one's mistaken conscience ${ }^{22}$.

Soldiers have a duty to disobey those orders that their conscience considers unjust. Moreover,

this duty to act in conformity with conscience is joined with a corresponding right to do so. If subjects doubt in regard to the justice of a war (and a fortiori if they are convinced of its injustice) the state may not compel them to serve ${ }^{23}$.

Grotius developed a ground-breaking concept: that conscience «does not only oblige to disobey in case of conscientious objections, but also confers a corresponding right and immunity to the conscientious objector ${ }^{24}$. If we translate this concept from the military to civil society, we can find in it the roots of the right (and moral duty) to civil disobedience. But is this moral duty also a legal duty? If so, the lawfulness/unlawfulness of a conduct is irrelevant, provided that such conduct is contrary to the dictates of conscience. In other words, guilty conscience is sufficient to establish criminal intent and there is no room for the traditional defence that a conduct ceases to be criminal for the sole fact that it is allowed - or even prescribed - by the law or by the authority. This issue was broadly discussed in relation to the Nuremberg Trials and, later, by the German American philosopher Hannah Arendt in her commentary to the Eichmann case ${ }^{25}$. Indeed, the fact of having acted in accordance with the rules and pursuant to orders of a superior was, notoriously, the core of the Nazis' defence strategy.

The Nuremberg Principles established the responsibility for war crimes of those who had «voluntarily aided and abetted illegal acts in a situation in which they

\footnotetext{
${ }^{21}$ Lovell, 2009, p. 163.

${ }^{22}$ Vermeulen, 1985, pp. 3, 7 and 13-14.

${ }^{23}$ Ibidem, p. 16.

${ }^{24}$ Ibidem, p. 16.

${ }^{25}$ In 1961 Hannah Arendt was commissioned by the New Yorker to write a reportage of the trial of the Nazi official Adolf Eichmann, who had been one of the major organizers of the Holocaust. Eichmann had been kidnapped by Mossad operatives in Argentina and brought to Jerusalem to be tried for his crimes. Eventually, he was sentenced to death and hanged. Arendt's account of the trial then became a book (Eichmann in Jerusalem: A Report on the Banality of Evil), published in 1964.
} 
had or should have had adequate knowledge of their character ${ }^{26}$. In the words of Hannah Arendt,

the Nazi criminal actions became possible because there existed an efficient bureaucratic structure, founded on a scrupulous respect for 'superior orders' and thus on order and discipline. It was the very existence of this modern administrative machinery that made the 'banality of evil' possible, with the most inhuman directives being carried out promptly and efficiently ${ }^{27}$.

The fact that "there were no voices from the outside to arouse his conscience ${ }^{28}$ constituted one of the main points of Eichmann's defence. And it was not just widespread passive acceptance: all kind of people cooperated with the Nazi Party, while knowing the Party's aims, thus making themselves accomplices to the Nazi crimes.

Coercion is typical of the military context and the refusal to obey military orders can lead to extreme consequences. However, it is also true that civilians also «tend to commit wrongful acts when commanded to do so by an authority figure ${ }^{29}$. This is the reason why the Tokyo War Crimes Judgment gave a broad interpretation of the Nuremberg Principles, concluding that

persons may be held responsible for violations of international law if: (1) [t]hey had knowledge that such crimes were being committed and having such knowledge they failed to take such steps as were within their power to prevent the commission of such crimes in the future, or (2) they are at fault in having failed to acquire such knowledge ${ }^{30}$.

Therefore, it is not only the soldiers, but also citizens and corporations that have a duty to disobey unlawful orders. Citizens who are «not just conscious and willing participants but enthusiastic and indeed fanatical instigators and perpetrators of the strategy ${ }^{31}$ put in place by the Government are complicit in it. This moral responsibility becomes legal responsibility when the citizen has aided and abetted the Government's crimes.

The same is true for corporations: in the Zyklon B trial, the Nuremberg Tribunal sentenced to death the directors of the German corporation who supplied poison gas to Nazi concentration camps, although they knew that the gas was going to be used on humans. The Tribunal concluded that the general rule "that those who conspired to commit international crimes, or crimes against humanity were complicit in the commission of those crimes ${ }^{32}$ was also applicable to corpora-

\footnotetext{
${ }^{26}$ Lambek, 1986, p. 489.

${ }^{27}$ Cassese, 2008, p. 483.

${ }^{28}$ Arendt, 2005 p. 74.

${ }^{29}$ Bohrer, 2018, p. 278.

${ }^{30}$ Lambek, 1986, pp. 489-491.

${ }^{31}$ Westra 2014, p. 189.

32 Ibidem, p. 159.
} 
tions. Other leading German industrialists were accused of having profited from the Nazi forced labour program and brought to trial in Nuremberg.

The relationship between the IBM company and the Nazi Government has been also discussed. During the 1930s, IBM sold a revolutionary data management system to the Government. According to some scholars, this system was «a key tool without which they would not have been able to implement their brutally efficient extermination program». Other scholars argue that the company was blameless because "the Nazis could have conducted their 'business' also without the assistance provided by IBM and that such business decisions were reasonable, morally neutral choices ${ }^{33}$.

Another case concerns the relationship between corporations and the South African Apartheid regime. In 2002, a group of citizens sued twenty multinational companies - among which General Motors, Ford and IBM - for complicity with the criminal regime. According to the plaintiffs, the companies had provided resources to the South African Government, while also exploiting cheap slave labour: such economic support and moral sanction was itself a crime ${ }^{34}$.

Overall, it seems clear that «if even soldiers, employed as they are by the most authoritarian organizations in the world, could not be shielded from culpability, then surely those employed by industry or corporations, cannot claim such a shield $»^{35}$. Moreover, «if the explicit orders of a direct superior must be questioned in the light of the legality and morality of the effects of obedience, then, all the more, the implicit 'orders' representing the interests of the shareholders of any corporate body, cannot be absolutely unquestionable $»^{36}$.

\section{The legal defences for civil disobedience}

While the above paragraph concerns the duty of disobedience, the issue analysed here is whether the right to disobedience is a legal right or only a moral right. According to a first view, a conduct is not allowed for the sole fact that it has moral value; conversely, the fact that an act lacks moral value does not make it unlawful. Therefore, saying that a person has done something wrong does not necessarily mean that he is blameworthy, if his motivations are valid. From another point of view, the moral right to disobey can be translated into a legal right. Accordingly, the right of political participation includes the right to challenge the Government's decisions, also through illegal acts of civil disobedience.

\footnotetext{
33 Ibidem, pp. 145-146.

${ }^{34}$ In re South African Apartheid Litigation. General Motors was the only company that agreed to a settlement with the plaintiffs. Part of the case was dismissed in 2015, while another part is still pending (Skinner, 2008, p. 323).

${ }^{35}$ Westra, 2014, p. 162.

${ }^{36}$ Ibidem, p. 162.
} 
There are two other possible defences for civil disobedience: necessity and self-defence. The necessity defence is based on the "reasonable belief that breaking the law is necessary to prevent the occurrence of a greater harm ${ }^{37}$. In other words, the disobedient behaviour is the lesser of two evils in comparison to the Government's actions. In particular, if the Government is committing an international crime, otherwise unlawful actions are justified as «attempts to stop or prevent the implementation of government policies that are believed to be in violation of international law $»^{38}$. Indeed, civil disobedience is «vital to straightening the role of international law as a basis for confronting the authorization of abuses under domestic laws and institutions ${ }^{39}$. However, the necessity defence places a heavy burden of proof on the defendant.

The proponents of the self-defence argument assert that «to remain non-violent totally is to allow the perpetuation of violence against people, animals and the environment. [Therefore], it is morally and legally permissible to respond with some degree of force in defence of principle or in protest against immoral laws and activities ${ }^{40}$. According to the majority of scholars, the use of force is justified - both from a moral and legal point of view - if it is focused and proportionate. Additionally, the right to self-defence involves «more than the defence of one's biological existence ${ }^{41}$ and concerns not only individuals, but also communities or even nations. For example, the whistle-blower has been described as someone who "engages in a form of self-defence " $^{42}$. He reveals the existence of harmful corporate practices, thus benefitting the affected stakeholders and the public in general. Self-defence has also been invoked in the context of communities or groups' fight against intolerable living conditions, for the right to self-determination or for the preservation of the environment.

The above-mentioned defences have received little recognition by courts. The first reason is that there are difficulties in applying the Nuremberg principles to civil disobedience. Even if the court accepts that individuals «have a duty under Nuremberg to stop government crimes, defendants would still encounter the judge's reluctance to regard civil disobedience as a legitimate means of discharging that duty" ${ }^{43}$. Secondly, "willingly violating a law as an act of civil disobedience is generally not covered by traditional defences, as most acts of civil disobedience do not involve imminent harm ${ }^{44}$.

According to an alternative view, it is the moral right to civil disobedience that

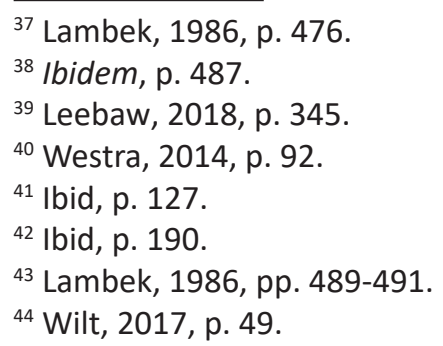


implies the permissibility of civil disobedient acts, independently of their justification. [This] does not mean that agents should have a legal right to disobey. What it does mean is that law enforcement officers should choose not to arrest agents, prosecutors should decide to drop criminal charges against defendants, judges should exercise leniency in sentencing, and juries should choose not to convict defendants ${ }^{45}$.

Consequently, while civil disobedience is still criminal, punishment is excluded, and the trial concludes with a verdict of «guilty but civilly disobedient ${ }^{46}$.

\section{A modern kind of civil disobedience: whistleblowing. The Wikileaks case}

The Wikileaks case is emblematic of the evolution of civil disobedience in the contemporary age. Edward Snowden was an employee of the technology security consulting firm Booz Allen Hamilton, a contractor of the U.S. National Security Agency. In 2013 he stole confidential documents with the intention of leaking them to the press. After he was charged with the theft of government property and violations of the 1917 Espionage Act, Snowden escaped to Hong Kong. Snowden's decision to flee abroad - instead of accepting the consequences of his actions and going to jail - was criticized. He was unfavourably compared to the 1960s American civil right activists who regarded punishment as a part of their struggle. However, it is undeniable that Snowden's whistleblowing activities are very different from the traditional protests against the establishment, both in their purpose and effect. They may inspire other people, but they would not prompt those «widespread uncoordinated acts of leaking, activism or other such disobedience, let alone any general breakdown of legal authority ${ }^{47}$ that are typical of civil disobedience.

Nonetheless, Snowden justified his actions as «a moral act of conscience and a public act of citizenship ${ }^{48}$, thus making a clear reference to civil disobedience. Some commentators define whistleblowing - together with hacking and distributed denial-of-service (DDoS) attacks - as an act of digital disobedience, that is a "politically motivated online lawbreaking ${ }^{49}$. Indeed, the unauthorized public disclosure of government documents by whistle-blowers is often the public's «best and only chance of finding out about, and ultimately addressing, government wrongdoing ${ }^{50}$.

As with civil disobedience, the right to freedom of expression is the most common defence for whistleblowing. However, public whistleblowing is more serious

\footnotetext{
${ }^{45}$ Delmas, 2018, pp. 69-70.

${ }^{46}$ Wilt, 2017, p. 52.

${ }^{47}$ Pineda, 2015, p. 6.

48 Ibid, p. 24.

${ }^{49}$ Scheuerman, 2018, p. 122.

${ }^{50}$ Boot, 2018, p. 71.
} 
than mere civil disobedience: the whistle-blower is not an ordinary citizen, but someone who uses his public position to disclose information of public interest. Moreover,

unauthorized disclosures can have various harmful consequences: they may disclose the identities of undercover agents, thus placing them at great risk; national security could be harmed by publicizing military documents which the enemy could use to its advantage; and public trust may be needlessly damaged if the disclosed information proves to be untrue or biased ${ }^{51}$.

\section{Whistleblowing}

involves a usurpation of power, the power to classify information, whereas civil disobedience activists merely protest against a particular policy that they oppose and aim to have reformed or repealed entirely by the democratic authority. The problem is not merely that whistle-blowers may pursue morally problematic ends, but that, in whistleblowing, they arrogate to themselves political power that properly belongs to our democratic representatives. The question is whether the right to do wrong can also accommodate such wrongdoing ${ }^{52}$.

Therefore, the question is whether an individual right-based defence of whistleblowing is possible. The same issue arises again like a fil rouge, connecting military duties, civil disobedience and now digital disobedience: the fact that someone follows the dictates of his conscience, or acts according to a subjective view of the common good, does give him the right to break the law? And if yes, what are the limits and boundaries of this right?

\section{Morality and criminal law: why civil disobedience is not a crime}

The question of when disobedience to the law is justified is certainly one of the "perennial questions in the history of humanity " $^{53}$. As mentioned above, duty and right to disobey are two faces of the same coin. Indeed, in some circumstances a right can be transformed into a duty. However, the contrary is also true: moral duties create legal rights. That is why recognizing that individuals have a duty to disobey is not enough, they must be granted the right to disobey unjust laws and orders.

While it is undeniable that the first and foremost obligation of the democratic citizens is the moral obligation to obey the law, it is also true that the "citizens' political duties are not exclusively fulfilled through acts of obedience ${ }^{54}$. When this is the case, the act of disobedience is not merely permissible, but required by the agent's own political obligations, even if it requires the use of force.

\footnotetext{
51 lbid, p. 83.

52 Ibid, pp. 80-81.

53 Jones, 2004, p. 319.

${ }^{54}$ Moraro, 2014, pp. 71-72.
} 
According to the traditional idea, the purpose of criminal law is the maintenance of social order. Therefore, "the most basic demand citizens ought to make of criminal law is that it contribute to securing the conditions of security and civil peace, thus sustaining civil society ${ }^{55}$. Clearly, there is no room for civil disobedience: political authority serves to provide a mechanism for peacefully resolving the differences. At the end of this political process «someone has to win, and someone has to lose; and, if we want differences to be resolved peacefully rather than through bloodshed ${ }^{56}$.

Yet, this approach appears too simple because it does not focus on the fundamental question of what should be criminalized and what should not be criminalized. When we consider this issue, the «moral justification must come first, and the concept of civil peace is too nebulous to provide any guidance ${ }^{57}$. Therefore, civil disobedience is not criminal because it is morally justified as the individual's effort to support high legal principles against the injustice committed by the authority. As expressed by a scholar, «while we can recognise the utility of political authority as an institution and have good reasons for subordinating ourselves to it, we act immorally as well as imprudently if we subordinate ourselves to it unconditionally ${ }^{58}$.

In other words, the civil disobedient stands for law and morality against the Government's wrongdoing. This, in essence, is the heart of one of the most beautiful tragedies of all times, Sophocles' Antigone. While the law of Thebes prohibited the burial of a traitor (her brother Polynices), Antigone decided to abide by the religious obligation to bury the dead, thus facing the extreme punishment. In this tragedy, "conscience witnesses the opposite demands of law and religion and orients the individual towards the latter ${ }^{59}$.

Antigone

stands for all those who break the laws of the establishment to obey more humane imperatives [and] is the archetype of those who, caught in the dichotomy between an order from the powers that be and respect for higher values, choose the latter, knowing full well they will be made to pay for their choice ${ }^{60}$.

The next question concerns the very possibility of establishing the criminal liability of those who obey superior orders or meet social expectations. Such prosecutions are problematic and being "entirely foreign to defendants' beliefs and their most fundamental convictions [may] render questionable or even defunct

\footnotetext{
${ }^{55}$ Bottoms, 2014, p. 234.

${ }^{56}$ Jones, 2004, p. 323.

${ }^{57}$ Bottoms, p. 2014, p. 233.

58 Jones, 2004, p. 320.

${ }^{59}$ Zucca, 2018, p. 130.

${ }^{60}$ Cassese, 2008, p. 476.
} 
basic purposes of criminal law, such as individual retribution ${ }^{61}$. According to strict positivism, someone like Eichmann cannot be held criminally liable for his actions because they were legal when committed. Moreover, if the conduct is not prohibited, there can be no criminal intent, i.e., the mens rea that is an essential part of any crime.

In her commentary on the Eichmann case, Hannah Arendt dismissed this point of view. In Arendt's philosophy the law is inseparable "from its animating principles, principles that cannot be reduced to positive laws and which she roots in the human condition ${ }^{62}$. The law is legitimate and binding when it has the citizens' consent. Consequently,

the moral relation of the citizen to the law lies in the obligation inherent in all promises. The moral duty of the citizen to the law is therefore a political duty, a duty that cuts both ways: a citizen must support and disobey. Politics, she argues, is not the nursery; instead, politics is the domain where obedience and support are equivalent terms and where the citizen is obligated to withdraw support whenever the originary promise - the spirit of the laws - has been broken ${ }^{63}$.

During the trial Eichmann admitted that he knew that what he was doing to the Jews was criminal, in the sense that it «offended nature» ${ }^{64}$. Although he found himself in a reality where "the moral maxims which determine social behaviour and the religious commandments had virtually vanished ${ }^{65}$, he was still able to tell right from wrong and understand that the Nazi laws were evil. That is why he was not only morally, but also legally bound to withdraw his support from such laws: his failure to do so justified his conviction.

The idea that obedience is equivalent to support is at the core of Arendt's philosophy. Of course, Arendt's analysis refers to a period when for a soldier (and even for a civil servant) there was no third option beyond obeying orders or disobeying at the price of their own life. And, even today, the military permits disobedience only within the limited boundaries of conscientious objection. The traditional view is that civil servants are in a similar position: that «resigning from office or refusing to sign up are the only responsible options ${ }^{66}$ for those who do not want to abide by the Government's laws. Therefore - although those constraints that are typical of the military world are absent from the civil service still there is no room for disobedience.

However, there is also an alternative view: that the civil servants should express their activism through their work inside the administration. Moreover, although

\footnotetext{
${ }^{61}$ Mann, 2020, pp. 147 and 154.

${ }^{62}$ Birmingham, 2014, p. 713.

63 Ibid, p. 703.

${ }^{64}$ Arendt, 2005, p. 105.

${ }^{65}$ Ibid, p. 125.

${ }^{66}$ Delmas, 2018, p. 246.
} 
they are ordinarily supposed to comply with the orders they receive, they may choose to disobey when those orders undermine the public good.

According to this view, whistleblowing - as an effort to terminate complicity in the Government's wrongdoing - is a form of «bureaucratic resistance from below to challenge unethical or unconstitutional policies and promote the public $\operatorname{good} »^{67}$. Indeed, scholars highlight how «leaks of this nature, which expose serious wrongdoing and abuses, promote the rule of law $\|^{68}$. The idea that what is traditionally considered as a crime can become not only an individual right, but also a political obligation is ground-breaking.

\section{Conclusion}

The year 2020 will be remembered as a crucial year in the history of civil disobedience. In the aftermath of George Floyd's death in Minneapolis in May 2020, protests - both peaceful and violent - have erupted across the United States and in other countries. The Black Lives Matter movement, which heads the protest, has been called "the civil rights movement of our time" " 9 .

Some commentators wondered what response the theorists of civil disobedience would give to the current climate of violence. For example, Martin Luther King never abandoned nonviolence as a personal philosophy and political tactic but endorsed violent demonstrations as "critical to redeeming America's racially wounded soul ${ }^{70}$. However, in the Floyd case, the 'natural' amount of violence that often accompanies the protests left space to vandalism on a vast scale. The movement itself condemned this outcome, and so did some old Afro-American activists who had been protagonists of the fight for the civil rights in the $1960 \mathrm{~s}^{71}$.

The recent events have triggered a widespread debate - especially among U.S. scholars - about the legitimacy of 'uncivil' disobedience. Someone pointed out that civility «is a moral duty in liberal democracy. Citizens of liberal democracies have a special duty to comport themselves in ways that nurture and preserve civic bonds. Aristotle talked about civic friendship ${ }^{72}$. Others, however, recognize that - just as civil disobedience - uncivil disobedience too can be «an appeal to higher law ${ }^{73}$. Indeed, in certain circumstances, violence can

contribute to advancing justice and democracy, by jolting the public into reco-

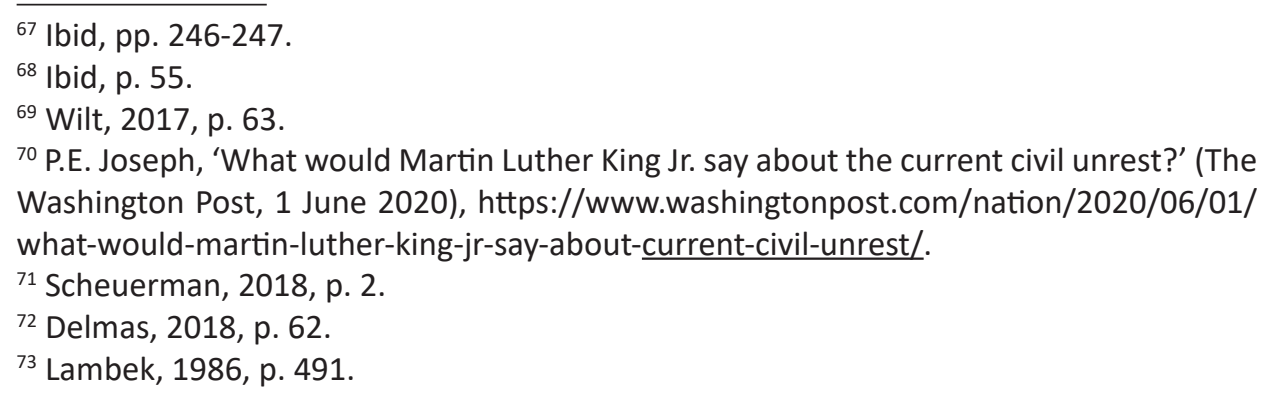


gnizing pressing claims of oppression. And even if acts of uncivil disobedience are counterproductive to the broader goal of affecting socio-political change, they may still constitute intrinsically valuable expressions of dissent, solidarity, and agency $^{74}$.

The issue must be framed in the broader debate on whether crime and other illegal actions might be an expression of political dissent, i.e. an answer to a perceived social injustice. According to this view, the so-called crimes of dissent «embody strategies through which political resistance can be manifested», triggering "a radical social transformation» that exposes "the limits of State authority and the follies of political power ${ }^{75}$. Some commentators have gone as far as to consider crime as an attempt at political reform from «the powerless against the powerful [...] in that people who do not maintain an ideological orientation in sympathy with a political majority are likely to have their dissent defined as criminal by the State ${ }^{76}$. Nonetheless, as the last months have shown, the most vulnerable communities are those most damaged by violence. Indeed,

the assertion that crime functions as a progressive and transformative act suffers from the paradox that the typical victims of crime are the people most in need of a socioeconomic revolution, such as women, racial and ethnic minorities, and the working class $^{77}$.

The risk is that those people who should benefit from disobedience end up being victims of it.

What conclusions can be drawn from this analysis? Pluralism is one of the most prominent features of our age: people tend to have multiple interests and different standards. Scholars highlight how historically «the decline of the nation states goes hand in hand with the rise of conscientious objections ${ }^{78}$. In an interesting historical parallel, we can notice that civil disobedience - to use the modern term - is a common feature of some unstable periods, from the decline of the Greek city states and post-Renaissance Italy, to our pluralistic age. Indeed, it is no coincidence that «conscientious voices are louder when political authorities lose their legitimacy ${ }^{79}$. In today's world, State sovereignty still has a central role: Governments define both the military policy and the boundaries of the right to civil disobedience. However, while in the past the Governments' power was virtually unlimited, today "State sovereignty, in its most basic sense, is being redefined. [...] States are now widely understood to be instruments at the service of their

\footnotetext{
${ }^{74}$ Delmas, 2018, p. 67.

${ }^{75}$ Lovell, 2009, pp. 65 and 69.

${ }^{76} \mathrm{Ibid}, \mathrm{p} .17$.

77 Ibid, p. 18.

${ }^{78}$ Zucca, 2018, p. 131.

${ }^{79}$ Ibid, p. 130.
} 
peoples, and not vice versa ${ }^{80}$. This is something that must be taken into account when setting the boundaries of criminal law.

\section{Bibliography}

Arendt H., 2005: Eichmann in Jerusalem: A Report on the Banality of Evil, London, Penguin Books

Birmingham P., 2014: Hannah Arendt's philosophy of law approach to international criminal law, in "International Criminal Law Review", 14(4-5), pp. 695-716

Bohrer Z., 2012: England and the superior orders defence choosing the middle path, in "Oxford University Commonwealth Law Journal", 12(2), pp. 273-294

Boot E.R., 2018: No Right to Classified Public Whistleblowing, in "Ratio Juris", 31(1), pp. 70-85

Bottoms A., 2014: Civil Peace and Criminalization, in R.A. Duff and others (eds), Criminalization: The Political Morality of the Criminal Law, Oxford, Oxford University Press, pp. 232-269

Burgess jr D.R., 2014: The politics of piracy: crime and civil disobedience in colonial America, Lebanon, University Press of New England

Cassese A., 2008: Abraham and Antigone: Two Conflicting Imperatives, in A. Cassese (ed), The Human Dimension of International Law: Selected Papers, Oxford, Oxford University Press, pp. 475-498

Delmas C., 2018: A duty to resist: when disobedience should be uncivil, Oxford, Oxford University Press

Hayes G. and Ollitrault S., 2018: Civil Disobedience, in I. Sommier and others (eds), Breaking Laws: Violence and Civil Disobedience in Protest, Amsterdam, Amsterdam University Press, pp. 123-241

Jones, P., 2004: Introduction: Law and Disobedience, in "Res Publica", 10(4), pp. 319-366

Joseph P.E., 2020: 'What would Martin Luther King Jr. say about the current civil unrest?', The Washington Post, 1 June 2020 (www.washingtonpost.com/ nation/2020/06/01/what-would-martin-luther-king-jr-say-about-current-civilunrest/)

Lambek B., 1986: Necessity and International Law: arguments for the legality of civil disobedience, in "Yale Law \& Policy Review", 5(2), pp. 472-492

Leebaw B., 2018: Justice and the faithless: The demand for disobedience in international criminal law, in "European Journal of International Relations", 24(2), pp. 344-366

\footnotetext{
${ }^{80}$ Walker, 2012, p. 433.
} 
Lovell J., 2009: Crimes of Dissent, New York, New York University Press

Mann I., 2020: Eichmann's Mistake: The Problem of Thoughtlessness in International Criminal Law, in "Canadian Journal of Law \& Jurisprudence", 33(1), pp. 145-181

Moraro P., 2014: Respecting Autonomy Through the Use of Force: the Case of Civil Disobedience, in "Journal of Applied Philosophy", 31(1), pp. 63-76

Nehushtan Y., 2017: Civic Conscience, Selective Conscientious Objection and Lack of Choice, in "Ratio Juris", 30(4), pp. 433-450

Pineda E., 2015: Civil Disobedience and Punishment: (Mis)reading Justification and Strategy from SNCC to Snowden, in "History of the Present", 5(1), pp. 1-30

Rawls J., 1999: The justification of Civil Disobedience, in W.A. Edmundson (ed), The duty to obey the law, Lanham, Rowman \& Littlefield, pp. 49-62

Scheuerman W., 2018: Civil Disobedience, Cambridge, Polity Press

Skinner G., 2008: Nuremberg's Legacy Continues: The Nuremberg Trials' Influencing on Human Rights Litigation in U.S. Courts under the Alien Tort Statute, in "Albany Law Review", 71(1), pp. 321-368

Thoreau H.D., 2008: Walden And On the Duty of Civil Disobedience, The Floating Press

Vermeulen B., 1985: Grotius on conscience and military orders, in "Grotiana", 6(1), pp. 3-20

Walker S.G., 2012: Lawful murder: Unnecessary killing in the law of war, in "Canadian Journal of Law \& Jurisprudence", 25(2), pp. 417-446

Westra L., 2014: Revolt Against Authority, Leiden, Brill

Wilt M.P., 2017: Civil Disobedience and the Rule of Law: punishing 'good' lawbreaking in a new era of protest, in "George Mason University Civil Rights Law Journal", 28(1), pp. 43-67

Zucca L., 2018: Is there a right to conscientious objection?, in S. Mancini and M. Rosenfeld (eds), The Conscience Wars: Rethinking the Balance between Religion, Identity and Equality, Cambridge, Cambridge University Press, pp. 127-148 